\title{
Огляди
}

DOI: 10.31793/1680-1466.2020.25-3.227

\section{Молекүлярні механізми утворення метастазів. Маркери метастазування при карциномах щитоподібної залози (огляд літератури)}

П.П. Зінич, В.М. Пушкарьов, М.Ю. Болгов, Б.Б. Гуда, В.В. Пушкарьов

ДУ «Інститут ендокринології та обміну речовин ім. В.П. Комісаренка НАМН України»

Резюме. Метастази є причиною 90\% смертей від солідних пухлин. Процес метастазування передбачає вихід ракових клітин із первинної пухлини, їх перехід у кровоносну, або іншу транспортну систему і, нарешті, колонізація та проліферація у віддаленому органі. В огляді описано процес розвитку метастатичної клітини, зумовлений генетичними, епігенетичними, позиційними змінами, сигналами оточуючих клітин. Під час епітеліальномезенхімального переходу пухлинні клітини частково і тимчасово дедиференціюються, змінюють свою форму в бік неполяризованої, рухливої, веретеноподібної клітини. Цей перехід дає можливість налагодити експресію генів та придбати фенотип стовбурових клітин. Розглядаються також механізми мобільності та інвазивності пухлинних клітин, процеси інтравазації, транспортування, хомінгу. Значна увага приділена утворенню преметастатичної ніші, яка характеризується імуносупресією, запальними процесами, інтенсивним ангіогенезом, пермеабілізацією судин, активним лімфангіогенезом, специфічним органотропізмом та високою ефективністю перепрограмування. Детально проаналізований процес колонізації метастатичної ніші пухлинними клітинами, участь у ньому клітин імунної системи, інших клітин крові, прогеніторів кісткового мозку, екзосом, які утворюються в оточенні первинної пухлини, метаболічних ферментів та прозапальних цитокінів. Акцент зроблено на процес метастазування пухлин щитоподібної залози (ЩЗ). Наведені та проаналізовані основні маркери метастазування для карцином Щ3 для всіх етапів метастатичного каскаду. Описані супресори метастазування, оцінений вплив мікрооточення пухлини, значення запальних процесів та інших патологій у виникненні і прогресії карцином ЩЗ.

Ключові слова: метастази, щитоподібна залоза, метастатична ніша, епітеліально-мезенхімальний перехід, міграція та інтравазація пухлинних клітин.

\footnotetext{
* Адреса для листування (Correspondence): ДУ «Інститут ендокринології та обміну речовин ім. В.П. Комісаренка НАМН України», вул. Вишгородська, 69, м. Київ, 04114

Україна. E-mail: pushkarev.vm@gmail.com

(с П.П. Зінич, В.М. Пушкарьов, М.Ю. Болгов, Б.Б. Гуда, В.В. Пушкарьов
} 
правополушарной локализацией ишемического очага.

4. Для пациентов с ЦА 1-2 стадии и СД2 не установлены возрастные и половые различия в показателях структурно-функционального состояния сердца.

5. Для пациентов мужского пола с СД2, перенесших ИИ, характерны большие размеры полости ЛЖ, УО, МОК и ОПСС, а статистически значимые меньшие размеры полости и большая толщина стенок ЛЖ наблюдаются после 60 лет.

\section{Список использованной литературы}

1. Badimon L, Vilahur G. Thrombosis formation on atherosclerotic lesions and plaque rupture. J Intern Med. 2014;276(6):618-632.

2. Bangalore S, Gong Y, Cooper-DeHoff RM, et al. 2014 Eighth Joint National Committee panel recommendations for blood pressure targets revisited: Results from the INVEST study. J Am Coll Cardiol. 2014;64(8):784-793.

3. Den Hartog AG, Achterberg S, Moll FL, et al. Asymptomatic carotid artery stenosis and the risk of ischemic stroke according to subtype in patients with clinically manifest arterial disease. Stroke. 2013;44(4):1002-1007

4. Gradman AH. Optimal blood pressure targets in older adults: How low is low enough? J Am Coll Cardiol. 2014;64(8):794-796.

5. Kernan WN, Ovbiagele B, Black HR, et al. Guidelines for the prevention of stroke in patients with stroke and transient ischemic attack: A guideline for healthcare professionals from the American Heart Association/American Stroke Association. Stroke. 2014;45(7):2160-2236.

6. Powers WJ, Derdeyn CP, Biller J, et al. 2015 American Heart Association/American Stroke Association Focused Update of the 2013 Guidelines for the Early Management of Patients with Acute Ischemic Stroke Regarding Endovascular Treatment: A Guideline for Healthcare Professionals From the American Heart Association/ American Stroke Association. Stroke. 2015;46(10):3020-3035.

7. Sha T, Huang YQ, Cai AP, et al. Prevalence and determinants of left ventricular geometric abnormalities in hypertensive patients: A study based on the updated classification system of left ventricular geometry Hellenic. J Cardiol. 2017;58(2):124-132.

8. Riecker A, Gröschel K, Ackermann H, Schnaudigel S, Kassubek J, Kastrup A. The role of the unaffected hemisphere in motor recovery after stroke. Hum Brain Mapp. 2015;31(7):1017-1029

9. Кондратюк ВЄ. Вікові особливості структурно-функціонального стану серця та судин, системної гемодинаміки та біоелектричної активності міокарда у хворих, що перенесли ішемічний інсульт на фоні артеріальної гіпертензії. Проблемы старения и долголетия. 2007;16(4):377-390 (Kondratyuk VYe. Age features of the structural and functional state of the heart and blood vessels, systemic hemodynamics and bioelectrical activity of the myocardium in patients Who had ischemic stroke on the background of hypertension. Problemy starenyya y dolholetyya. 2007;16(4):377-390).

10. Кондратюк ВЄ. Особливості структурно-функціонального стану серця та системної гемодинаміки у хворих старшого віку, які перенесли ішемічний інсульт на тлі артеріальної гіпертензії, залежно від локалізації вогнища ураження. Кровообіг та гемостаз. 2008;(1):43-49 (Kondratyuk VE. The peculiarities of the structural and functional state of the heart and systemic hemodynamics in elderly patients, who have an ischemic stroke with arterial hypertension depending on the location of the lesion. Krovoobih ta hemostaz. 2008;(1):43-49).

11. Кондратюк ВЄ. Статеві відмінності структурно-функціонального стану серця та судин, системної та інтракардіальної гемодинаміки, біоелектричної активності та гомогенності міокар- да у хворих на гіпертонічну хворобу літнього віку з супутнім цукровим діабетом 2 типу. Проблемы старения и долголетия. 2009;18(2):210-222 (Kondratyuk VYe. Gender differences in the structural and functional state of the heart and blood vessels, systemic and intracardiac hemodynamics, bioelectrical activity and homogeneity of the myocardium in elderly patients with hypertension and concomitant type 2 diabetes. Problemy starenyya y dolholetyya. 2009;18(2):210-222).

12. Кондратюк ВЄ. Особливості змін електричної гомогенності міокарда у взаємозв'язку з показниками структурно-функціонального стану серця у хворих старшого віку, які перенесли ішемічний інсульт, на тлі артеріальної гіпертензії. Серце і судини. 2013;(2):43-54 (Kondratyuk VE. The peculiarities of changes in the electrical homogeneity of the myocardium in relation to the indicators of the structural and functional state of the heart in elderly patients, who have an ischemic stroke with arterial hypertension. Sertse i sudyny. 2013;(2):43-54).

(Надійшла до редакиії 29.07.2020 р.)

\section{Вікові і статеві відмінності структурно- функціонального стану серця в пацієнтів із церебральним атеросклерозом і цүкровим діабетом}

\section{В.Є. Кондратюк' ${ }^{1}$ М.С. Черська}

${ }^{1}$ Національний медичний університет ім. О.О. Богомольця ${ }^{2}$ ДУ «Інститут ендокринології та обміну речовин ім. В.П. Комісаренка НАМН України»

Резюме. Цереброваскулярні захворювання - одна 3 найважливіших причин захворюваності і смертності серед дорослого населення. Мета дослідження: провести порівняльний аналіз морфо-функціональних змін серця, інтракардіальної та системної гемодинаміки в пацієнтів похилого віку з церебральним атеросклерозом (ЦА) 1-3 стадії і цукровим діабетом 2-го типу (ЦД2), у тому числі в залежності від півкульної локалізації ішемічного вогнища і визначити вікові і статеві відмінності в даній категорії пацієнтів. Матеріал і методи: у комплексному дослідженні взяли участь 229 пацієнтів із ЦА 1-3 стадії і ЦД2. Пацієнти були розділені на 4 групи: 1-а група - перенесли ішемічний інсульт (II) у правій півкулі (ПП), 2-а група — перенесли II у лівій півкулі (ЛП), 3-я група - із ЦА 1-2 стадії (без II — група порівняння) і 4-а група загальна група пацієнтів, які перенесли ішемічний атеротромботичний інсульт (II). Дизайн - дослідження просте, проспективне, нерандомізоване, із послідовним включенням пацієнтів. Результати та обговорення: Порівняні між собою групи статистично значимо розрізнялися за індексом ЛП, індексом кінцево-діастолічного розміру, індексом кінцево-систолічного розміру і товщиною стінок лівого шлуночка (ЛШ). Міжпівкульні відмінності були зареєстровані тільки у відношенні величини ударного індексу Ексцентрична дилатаційна гіпертрофія ЛШ (ГЛШ) найбільш часто спостерігалася в пацієнтів з II - у 2,2 рази частіше, ніж у пацієнтів із ЦА 1-2 стадії, а концентрична дилатаційна ГЛШ частіше зустрічалася в пацієнтів із ЦА 1-2 стадії - в 1,8 раза частіше, ніж у пацієнтів із ІІ. Міжпівкульні відмінності спостерігалися тільки у відношенні III i V типів ГЛШ. Для пацієнтів із ЦА 1-2 стадії і ЦД2 не встановлені 
вікові і статеві відмінності в показниках структурно-функціонального стану серця. Для пацієнтів, які перенесли II, із ЦД2 характерні такі вікові і статеві відмінності: так, великі розміри порожнини ЛШ ударного об'єму (УО), хвилинного обсягу кровотоку (ХОК) і загального периферичного опору судин (ЗПОС) статистично значимо притаманні чоловікам, а статистично значимо менші розміри порожнини ЛШ і велика товщина стінок ЛШ спостерігаються після 60 років. Висновки: у пацієнтів із ЦА 1-3 стадії спостерігаються статистично значущі відмінності морфо-функціональних змін серця, інтракардіальної та системної гемодинаміки і геометрії ЛШ, причому деякі з цих відмінностей носять «півкульний» характер, а вікові статеві відмінності характерні тільки для пацієнтів з ІІ та ЦД2.

Ключові слова: церебральний атеросклероз, цукровий діабет, геометрія лівого шлуночка, міжпівкульні відмінності, вікові і статеві відмінності.

\section{Age and sex differences in the structural and functional state of the heart in patients with cerebral atherosclerosis and diabetes mellitus}

\author{
V.Ye. Kondratiuk ${ }^{1}$, M.S. Cherskaya ${ }^{2}$ \\ ${ }^{1}$ Bogomolets National Medical University \\ ${ }^{2} \mathrm{SI}$ «V.P. Komisarenko Institute of Endocrinology and Metabolism, Natl. \\ Acad. Med. Sci. of Ukraine»
}

Abstract. Cerebrovascular diseases are one of the most important causes of morbidity and mortality in the adult population. Objective: to conduct a comparative analysis of morphological and functional changes in the heart, intracardiac and systemic hemodynamics in elderly patients with cerebral atherosclerosis (CA) of grade 1-3 and type 2 diabetes mellitus (T2D), depending on the hemispheric localization of the ischemic focus, and to determine age and sex differences in these ones. Material and methods: 229 patients with CA of grade 1-3 and T2D took part in a complex study. The patients were divided into 4 groups: $1^{\text {st }}$ group - those who had an ischemic stroke (IS) in the right hemisphere (RH), $2^{\text {nd }}$ group - those who had IS in the left hemisphere LH), $3^{\text {rd }}$ group - with grade 1-2 CA (without IS - a comparison group) and $4^{\text {th }}$ group - the general group of patients after ischemic atherothrombotic stroke (IS). The design was a simple, prospective, non-randomized study with consecutive enrollment of patients. Results and discussion: The compared groups statistically significantly differed in the LH index, end-diastolic size index, end-systolic size index and left ventricular (LV) wall thickness. Hemispheric differences were registered only in relation to the stroke index (SI) value. Eccentric dilated LVH was most often observed in patients with IS -2.2 times more often than in patients with CA, and concentric dilated LVH was more common in patients with CA - 1.8 times more often than in patients with IS. Interhemispheric differences were observed only in relation to types III and V of LVH. For patients with grade 1-2 CA and T2D, age and sex differences in the structural and functional state of the heart have not been established. For patients undergoing IS with T2D, the following age and sex differences are characteristic: for example, large sizes of the LV cavity, SV, MCV are statistically significantly inherent in men, and statistically significantly smaller sizes of the LV cavity and greater LV wall thickness are observed after 60 years. Conclusions: in patients with CA of grades 1-3, statistically significant differences are observed in morpho-functional changes in the heart, intracardiac and systemic hemodynamics and LV geometry, and some of these differences are of a «hemispheric» nature, and age and sex differences are characteristic only for patients with IS and T2D.

Keywords: cerebral atherosclerosis, diabetes mellitus, geometry of the left ventricle, hemispheric differences, age and sex differences.

Для цитування: Кондратюк BE, Черская MC. Возрастные и половые различия структурно-функционального состояния сердца у пациентов с церебральным атеросклерозом и сахарным диабетом. Ендокринологія. 2020;25(3):215-226. DOI: 10.31793/16801466.2020.25-3.215.

Відомості про авторів: Віталій Євгенович Кондратюк, д-р мед. наук, проф., ORCID: 0000-0002-4891-2338; Марія Сергї̈вна Черська, канд. мед. наук, ORCID: 0000-0002-3689-2683.

Особистий внесок: В.Є. Кондратюк - аналіз проблеми, розробка концепції дослідження та редагування статті; М.С. Черська планування та проведення дослідження, обробка і аналіз результатів, написання статті.

Фінансування: стаття підготовлена в рамках бюджетного фінансування Національною академією медичних наук України.

Декларація з етики: автори задекларували відсутність конфлікту інтересів і фінансових зобов'язань. 
Огляди

\section{Процес метастазування}

Метастази є причиною 90\% смертей від солідних пухлин. Процес метастазування передбачає вихід ракових клітин із первинної пухлини, їх перехід у кровоносну або іншу транспортну систему i, нарешті, колонізацію та проліферацію у віддаленому органі.

Ознаками раку є імморталізація, геномна нестабільність, стійкість до апоптозу, змінений обмін речовин та здатність до інвазіі/ метастазування. Ознаки включають декілька критичних аспектів щодо взаємодії пухлинних клітин із підтримуваним стромою ангіогенезом, сприяння запальним процесам, ухилення від імунітету, стійкість до гальмування росту та відносну автономність. Характерними ознаками метастазів є мобільність та інвазивність клітин, модуляція мікросередовища, пластичність і колонізація вторинних сайтів [1].

Зараз визнано, що метастазами є виразні та унікальні підмножини клітин, які емігрували з первинної пухлини та за поведінкою, генетикою і біохімією відрізняються від клітин, що залишилися в первинній пухлині. Кожна метастатична клітина повинна пройти низку послідовних етапів, які називаються метастатичним каскадом [1].

Розвиток метастатичної клітини. Так само, як більшість пухлин є клональними за походженням, майже всі метастази виникають 3 однієї клітини [2, 3]. Щоб досягти розміру, коли пухлинна маса діагностується клінічно $\left(>10^{10}\right.$ клітин), вона повинна розвинути судинну мережу за допомогою ангіогенезу, мобілізувати вже наявну судинну мережу або сформувати трубки, які анастомозують із капілярами [4].

У межах пухлини клітини є морфологічно, біохімічно та генетично неоднорідними $[5,6]$. Відмінності в їх поведінці можуть бути зумовлені генетичними, епігенетичними, позиційними або часовими чинниками. Генетична гетерогенність належить до притаманних властивостей самих пухлинних клітин і демонструється експериментально шляхом виділення відносно стабільних клонів, які відрізняються один від одного в межах даного фенотипу. Епігенетична гетерогенність належить до перехідних хімічних модифікацій ДНК або хроматину, які призводять до селективної просторово-часової регуляції транскрипції генів для клітини залежно від умов навколишнього середовища (доступність кисню, фактори росту, рН та ін.) [5]. На молекулярному рівні більшість генетичних змін, що переважають на пізніх стадіях прогресування пухлини, пов'язані 3 канцерогенезом, інвазивністю та метастазами. Однієї генетичної зміни недостатньо для набуття здатності клітин до метастазування потрібні комбінації генетичних та епігенетичних змін [7]. Крім того, клітини раку можуть сприймати сигнали оточуючих клітин як пухлинних, так і стромальних.

Вважається, що геномна нестабільність $є$ рушійною силою прогресування пухлини. По мірі виникнення нових субпопуляцій пухлинних клітин, селективний тиск, що накладається конкуруючими пухлинними клітинами, а також реакція господаря та умови мікросередовища призводять до коеволюції пухлин та клітин строми. Одноклітинне клонування демонструє існування метастатичних та неметастатичних клітин у межах однієї пухлинної маси. Наявність метастазів є результатом утворення спеціалізованих субпопуляцій, наділених усіма ознаками метастатичного процесу. Про відмінність між утворенням пухлини та метастазів свідчить наявність сімейства генів, відомих як супресори метастазів, продукти яких блокують метастази, не перешкоджаючи розвитку первинної пухлини [8]. Тому метастази не можуть бути ознакою всіх клітин первинної пухлини.

Проте, мутаційно-селекційна теорія прогресування пухлини має і противників. Дехто стверджує, що надбання інвазивної і метастатичної поведінки є скоріше повторенням процесу, який відбувається під час ембріогенезу epithelial-to-mesenchymal transition (EMT).

Оскільки інвазивні клітини часто змінюють свою форму в бік неполяризованої, рухливої, веретеноподібної клітини, що нагадує фібробласт, дехто вважає, що неопластичні клітини дедиференціюються до більш мобільного фенотипу мезенхімальної клітини. ЕМТ ембріогенезу та ЕMT раку не є еквівалентними на молекулярному рівні, проте мають багато спільних ознак. ЕМТ характеризується втратою специфічного для епітелію Е-кадгерину 3 адгезивних контактів та переходу від експресії кератинів, як основних проміжних філаментів, до мезенхімальних віментинових 
проміжних філаментів. Зрештою, епігенетичні механізми та клітинна пластичність можуть грати більшу роль у прогресуванні пухлини до злоякісності, ніж мутації та селекція [9].

Існує концепція, що віддалені метастази виникають із невеликої, неоднорідної фракції cancer stem cells (CSC). Під час ЕMT пухлинні клітини частково і тимчасово дедиференціюються. Цей перехід дає можливість активувати експресію генів і набути фенотипу стовбурових клітин для самозбереження та розмноження. Нещодавні дослідження CSC виявили, що ці клітини мають особливу імуноредагуючу здатність - процес, який змушує імунну систему сприяти канцерогенезу та метастазуванню [10, 11].

Утворення пре-метастатичної ніші. Процес метастазування починається задовго до виявлення пухлини. Під час росту первинної пухлини високий рівень геномної нестабільності призводить до еволюції клітин, внаслідок чого вони набувають нових характеристик [1]. $\mathrm{C}$ кілька ознак, що визначають пре-метастатичну нішу: імуносупресія, запалення, інтенсивний ангіогенез, пермеабілізація судин, активний лімфангіогенез, специфічний органотропізм і висока ефективність перепрограмування [12, 13]. На основі відбору метастатичних субпопуляцій із суміші пухлинних клітин, процес придбання нових ознак, принаймні деяких із них, є перманентним. Однак здатність метастатичних клітин до регенерації неметастатичних популяцій говорить про те, що деякі надбанні властивості є тимчасовими. Протягом усього процесу клітини адаптуються до нових середовищ і реагують на сигнали, отримані від інших пухлинних клітин і строми. Вони повинні набути здатності виживати та пристосовуватись до кожного селекційного етапу метастатичного процесу [1].

Перед тим, як покинути пухлину, клітини первинних пухлин зв'язуються з іншими частинами організму для формування преметастатичної ніші [14]. Низка розчинних факторів, частина з яких перебуває в середині позаклітинних везикул, таких як екзосоми, встановлюють зв'язок із популяціями гемопоетичних і мезенхімальних стовбурових клітин [15-17]. Стовбурові клітини мобілізуються і потрапляють у вторинне мікросередовище ділянки, які згодом стануть метастазами, та адаптують його шляхом реструктуризації позаклітинного матриксу для утворення середовища, придатного для вторинного росту [18].

Пре-метастатична ніша складається 3 гетерогенної суміші клітин строми, судин, інших підтримуючих клітин та позаклітинного матриксу. Клітини кісткового мозку (макрофаги, гранулоцити, гематопоетичні клітинипопередники, мезенхімальні стовбурові клітини і ендотеліальні клітини-попередники) складають основу пре-метастатичної ніші [13].

Метастатичні ракові клітини, які надекспресують Jagged $(J A G)$ - ліганд сигнального шляху Notch, активують як гематопоетичні остеокласти, так і мезенхімальні остеобласти, зв'язуючись 3 Notch i сприяюючи росту пухлинних клітин та інвазії в кістки. Фактори, що секретуються пухлинами - tumor-derived secreted factors (TDSF) мають вирішальне значення для формування підтримуючого мікросередовища в метастатичних ділянках. Хемокіни та цитокіни, утворені в клітинах первинної пухлини, перепрограмовують віддалені тканини і сприяють створенню пре-метастатичної ніші [12].

Велику роль у перепрограмуванні мікросередовища відіграють екзосоми, які походять із пухлинних або стромальних клітин. Екзосоми - невеликі мембранні везикули до 100 нм, які утворені з пізніх ендосом [13]. Вони містять цитокіни, фактори транскрипції, фактори росту, miRNA, LncRNA та інші біологічно активні молекули [19]. Екзосоми беруть участь у зв’язках між клітинами за допомогою молекул, якими збагачені їх мембрани, шляхом перебудови мікросередовища органів-мішеней та сприяння формуванню пре-метастатичної ніші [20]. Вони широко розповсюджені в плазмі крові, спинномозковій рідині та ін. Екзосоми, збагачені специфічними для конкретного типу раку miRNA та LncRNA, можуть використовуватися, як біомаркери прогресування пухлини [21].

Мобільність та інвазивність. Внутрішньо властивою для процесу метастазування є здатність пухлинних клітин мігрувати. Інвазією, що визначає злоякісність пухлини, є здатність пухлинних клітин порушувати базальну мембрану та проникати в основу строми. Така здатність є необхідною, але не достатньою [1]. Вважалося, що міграція передусім пов’язана 
3 реорганізацією цитоскелету та реакцією на хемоатрактанти, а напрямок руху клітин пов'язаний із реакціями на атрактантні сигнали. Автокринні реакції на фактори мобільності, такі як лізофосфатидинова кислота, що утворюється шляхом розщеплення лізофосфоліпазою D лізофосфатидилхоліну, hepatocyte growth factor (HGF)/scatter factor (SF), який взаємодіє зі своїм рецептором с-Met, призводять до хемокінетичної активності. Спрямованість руху є результатом хемотаксису (за градієнтом концентрації розчинних чинників) або гаптотаксису (за градієнтом локалізованих факторів) [22].

При ЕМТ відбувається down-регуляція епітеліальних маркерів та ир-регуляція мезенхімальних генів. Цей процес ініціюється головними регуляторами EMT, такими як фактори транскрипціï Slug, Snail i Twist, та супроводжується епігенетичним пригніченням епітеліальних генів (включно з CDH1), що сприяе міграції клітин та інтравазації в циркуляцію. Шлях трансформуючого фактора росту transforming growth factor- $\beta$ (TGF- $\beta$ )/small mother against decapentaplegic (Smad) відіграє вирішальну роль у регулюванні цієї ранньої метастатичної події. Під час інтравазації TGF- $\beta$ сприяє надекспресії онкогену MAFK (musculoaponeurotic fibrosarcoma oncogene family protein K) для індукції ЕMT та посилення інвазії. Програма ЕМТ, що регулюється сигналінгом TGF- $\beta / \mathrm{Smad}$, також включає білок Wiskott-Aldrich syndrome protein family verprolin-homologous protein 3 (WAVE3) 3 ciмейства Wiskott-Aldrich syndrome protein (WASP)/WAVE, що зв'язує актин [23].

Інвазивність вимагає зміни морфології та фенотипу клітин, а також зміни навколишнього середовища. Динамічно регулюються три важливі процеси, які включають адгезію, реорганізацію extracellular matrix (ECM) та мобільність. Ці процеси пов'язані з актиновим цитоскелетом та такими ефекторами, як Rho GTРази та Arp2/3-комплекси [24].

Епітеліальні клітини зазвичай утворюють поляризовані листки, які підтримуються щільними контактами та десмосомами. Вони закріплені на базальній мембрані гемідесмосомами, проміжними філаментами, інтегриновими контактами та організованим актиновим цитоскелетом. Для інвазії клітини зменшують адгезію як між клітинами, так і між клітинами i матриксом, одночасно реорганізуючи ЕCM і посилюючи мобільність клітин. Структурні і функціональні білки, які регулюють адгезію та міграцію клітин, є ключовими мішенями сигнальних шляхів, контрольованих онкогенами і супресорами пухлин, і дають можливість зрозуміти, як онкогенна трансформація призводить до розвитку інвазивного фенотипу. Нормальні тканини розділені базальними мембранами і фасціями, які розмежовують і організують фізіологічні функції.

Позаклітинний матрикс формує каркас для взаємної організації клітин та просторових сигналів, що впливають на їх поведінку [25]. Матрикс складається 3 білків, насамперед трьохспіральних колагенів та глікопротеїнів - ламінінів, фібронектину і протеогліканів. Базальні мембрани - це спеціалізований ECM, який утворює бар'єр, що відокремлює поляризовані епітеліальні, ендотеліальні та м'язові клітини від підлеглих тканин. ЕСМ взаємодіє з багатьма молекулами - продуктами секреції різних клітин, і слугує сховищем для регуляторних білків і факторів росту. Взаємодія клітин із молекулами ЕСМ визначає їх здатність до виживання, росту, диференціації та міграції [26].

Мобільність є необхідною, але недостатньою умовою для переходу клітини 3 пухлини в кров. Зокрема, клітини повинні прикріплюватися та створювати проходи через ECM. Тому адгезія необхідна для того, щоб клітини могли прикріплюватися до матриксу, але вона не повинна бути настільки сильною, щоб клітини не могли рухатися через матрикс. Адгезія виникає за участі ряду спеціальних молекул, насамперед, трансмембранних глікопротеїнів - інтегринів [27]. Внутрішньоклітинні сигнальні шляхи можуть модулювати міцність клітинної адгезії (сигналінг зсередини назовні), а зміни клітинної адгезї̈ можуть змінювати клітинний фенотип (сигналінг ззовні в клітину). Крім того, інтегрини взаємодіють з іншими молекулами клітинної поверхні, опосередковуючи реакцію на фактори росту.

Позаклітинні матриці перебудовуються протеолітичними ферментами, що виробляються безпосередньо пухлинними клітинами або клітинами, асоційованими 3 ними. 
Ферменти, що сприяють деградації матриксу та полегшують інвазію пухлинних клітин, включають серинові протеїнази (плазмін, активатор плазміногену, сепраза, гепсин та кілька калікреїнів), цистеїнові протеїнази (катепсини В і К), аспартилові протеїнази (катепсини D i E) і металозалежні протеїнази з родини matrix metalloproteinases (MMP) та родини металопротеїназ a disintegrin and metalloprotease (ADAM).

Інші ферменти, що руйнують матрицю (гепараназа і ендоглікозидази, розщеплюють гепарансульфат протеоглікани і гіалуронову кислоту) також пов'язані з прогресуванням та інвазією пухлини. Експресія та активність багатьох з 23 металопротеїназ сімейства MМР, що руйнують матрикс, корелюють із прогресуючим раком [1].

Аналогічно, активатор плазміногену/ плазмінна система залучені в інвазивні процеси, a urokinase-type plasminogen activator (uPA) та plasminogen activator inhibitor-1 (PAI-1) є прогностичними маркерами раку молочної залози [28]. Ендогенні інгібітори, такі як tissue inhibitor of metalloproteinase (TIMP), serine protease inhibitors (serpins) та інгібітори цистеїнової протеази (cystatin), є важливими регуляторами протеолітичної функції, деградації та активації протеаз.

Таким чином, міграція клітин потребує узгодженої адгезї між клітинами та між клітинами і матриксом, деградації матриксу та активності цитоскелету. Під час міграції та інвазії клітини організовують адгезивні, протеолітичні та мобільні компоненти в спеціалізовані структури - інвадоподії [29]. Міграція неопластичних клітин може бути попередньо запрограмованою і спрямована до транспортних систем (судинна і лімфатична системи), оскільки транзит клітин через ці системи забезпечує можливості для їх найширшого розповсюдження за найкоротший час.

Міграція не здійснюється лише завдяки властивостям пухлинної клітини. Диференційно активововані вроджені імунні клітини можуть чинити позитивний або негативний вплив. Протипухлинними імунними клітинами є N1 нейтрофіли, або M1 макрофаги. На відміну від цього, популяції поліморфноядерних клітин або макрофагів, що сприяють інвазії та міграції пухлинних клітин, позначаються відповідно N2 та М2 [30].

Інтравазащія. Після місцевої інвазії клітина має потрапити в транзитну систему. У випадку метастазування через кров, процес називається інтравазацією, що вимагає часткової деградації ЕСМ і базальної мембрани під ендотеліальними клітинами судин. Пухлинні клітини проникають між ендотеліальними клітинами, просуваючи філоподію в просвіт судини. Вони потрапляють у кровоносну або лімфатичну судину чи в порожнини тіла найчастіше, вклинюючись між клітинами в місцях контактів без порушення щільних сполучень між ними [1]. Аномальна судинна система, що утворюється внаслідок ангіогенезу в пухлині, є легким бар'єром для пухлинних клітин.

Виявлено, що активація рецептора C-X-C chemokine receptor type 4; CD184 (CXCR4) його лігандом chemokine $\mathrm{C}-\mathrm{X}-\mathrm{C}$ motif ligand 12 (CXCL12) або angiopoietin-like 4 (ANGPTL2) індукує сигналінг mixed-lineage kinase 3 (MLK3) та extracellular-signal-regulated kinase (ERK1/2), сприяє інтравазації і призводить до розвитку метастазів у легені та кістки. Водночас, трансендотеліальна міграція та інвазія клітин раку в судинну систему може інгібуватися супресорами метастазів, такими як ТР63, leukemia inhibitory factor receptor (LIFR), lysyl oxidase-like 4 (LOXL4), forkhead box F2 (FOXF2), single-stranded DNA-binding protein (SSBP1), RAB1B i TGF- $\beta$ Inducible Early Gene-1 (TIEG1), KLF10. Таким чином, міграційний та інвазивний потенціал пухлинних клітин визначається балансом активності цих молекул [23].

Транспортування та дисемінащія. Після потрапляння в транспортний компартмент пухлинні клітини можуть поширюватися в його межах. Частота потрапляння пухлинних клітин у судину становить $\sim 1-4 \times 10^{6}$ клітин на грам пухлини на день. Процес успішного метастазування є малоефективним ( $<<0,01 \%)$ [1]. Рух всередині судин або порожнин може бути активним та пасивним.

При дисемінації характеристики circulating tumor cells (CTC) широко варіюють. Так, у судинній мережі виявлено повний набір маркерів, пов'язаних із епітеліальними або мезенхімальними характеристиками. Ефективність метастазування може зрости, якщо пухлинні 
клітини зберігають структурну емболію, як гомотипічну - тільки пухлинні клітини, так і гетеротипічну - пухлинні клітини-лейкоцити, -тромбоцити, -фібрин, або якщо вони укладені у фібринові згустки [31]. Великі згустки більш ефективно затримуються при зменшенні діаметра судини. Останне частково пояснює, чому переважна більшість метастазів, як правило, утворюється в першому ж капілярному руслі на шляху клітин, які утворюють метастази. СТС демонструють змінені патерни експресії генів, частково через епігенетичні модифікації [32].

У кровотоці пухлинні клітини перебувають у тісному контакті з лейкоцитами та іншими компонентами імунної системи. Протягом усього транзиту клітини повинні уникати імунних атак. Це відбувається шляхом downрегуляції антигенів, секреції факторів, які змушують імунну систему розпізнавати пухлинну клітину, як нормальну, або прямим знищенням імунних клітин. У цей час пухлинні клітини залишаються слабо адгерентними і схильними до анойкісу - форми загибелі клітин, яка спричинена відсутністю адгезії, контактів з іншими клітинами та ЕСМ [1].

Після потрапляння в кровоносні судини, циркулюючі пухлинні клітини експресують антиапоптотичні білки, що дозволяє їм виживати, приєднуватися до вторинних ділянок та інфільтрувати їх. Показано, що рецептор neurotrophic tyrosine kinase receptor (TRKB) пригнічує анойкіс через шлях phosphatidylinositol 3-kinase PI3K/Akt [23].

Зупинка (арешт) клітин, судинна адгезія та екстравазащія. У процесі кровообігу пухлинні клітини або затримуються через фізичні обмеження, такі як діаметр мікросудин, або пристають до інтимальних шарів судини. Ендотеліальні клітини судин є першим бар'єром для виходу метастатичних клітин із судин, хоча клітини можуть приставати до відкритої базальної мембрани, що лежить в основі ендотелію.

У вищих хребетних є три типи інтимальних структур судин - безперервні, зі щілиновидними отворами та фенестровані. Більшість ендотеліальних клітин утворюють щільні контакти і мають суцільну нерозривну базальну мембрану під ними. Бар'єри ендотелію та базальної мембрани сприяють нормальній функції тканин і створюють додаткові перешкоди, через які повинні проходити пухлинні клітини. Ендотеліальні клітини кожної тканини експресують унікальні маркери, що презентують тканинні сайти, які пухлинні клітини можуть розпізнавати та селективно приєднуватися [1].

Показано, що початкове прикріплення ракових клітин переважно відбувається в місцях контактів (сполучень) клітин ендотелію 3 подальшою ретракцією ендотелію та адгезією ракових клітин до базальної мембрани. Ще ефективніше пухлинні клітини прикріплюються до ділянок, де відбувається запалення, що пояснює більш часте виникнення метастазів у місцях ураження тканин [33]. Після трансендотеліальної міграції ракові клітини стикаються з базальною мембраною, виділяють протеїнази, деформуються в процесі протискання між клітинами та через отвори в матриксі і починають процес колонізації.

Екстравазація - це перехід із судини в паренхіму органу. Час між відшаруванням клітин від первинної пухлинної маси до реадгезії на вторинних сайтах становить хвилини. Іноді пухлинні клітини можуть приєднуватися до ендотелію, виживати та зростати внутрішньосудинно без екстравазації [1].

Під час екстравазації TGF- $\beta$ індукує через сигнальний шлях Smad експресію ANGPTL4, підвищений рівень якого посилює затримку пухлинних клітин у легенях, руйнує судинні ендотеліальні клітинні зв'язки і збільшує проникність легеневих капілярів для трансендотеліального проходження клітин. Також підкреслюється важливість синергетичного ефекту генів epiregulin (EREG), cyclooxygenase-2 (COX2), MMP1 і MMP2 у сприянні метастатичній екстравазації в легені [23].

Колонізація. Для колонізації вторинних тканин потрібні ті ж елементи, що й для росту первинної пухлини. Для поділу клітин повинно бути достатньо кисню та поживних речовин. Початковий ріст метастазів може відбуватися за відсутності ангіогенезу, але об'єм понад 1 мм $^{3}$ вимагає охоплення існуючих судин і розвитку нових самими пухлинними клітинами [34]. Встановлення підтримуючого метастатичного середовища, пре-метастатичної ніші, відбувається до прикріплення ракових клітин. Елементи сприятливого середовища 
включають vascular endothelial growth factor receptor (VEGFR), прогенітори кісткового мозку, myeloid-derived suppressor cells (MDSC), регуляторні Т-клітини (Treg) та нейтрофіли [35]. Ці клітини змінюють мікросередовище через секрецію запальних та імуносупресивних цитокінів, що сприяє метастазуванню. Також спостерігається накопичення метаболічних ферментів (включаючи indoleamine-pyrrole 2,3-dioxygenase (IDO) i аргіназу), які пригнічують проліферацію і активацію Т-клітин та інтенсивна експресія лігандів, (таких як FasL, programmed cell death protein 1 (PD-1), cytotoxic T-lymphocyteassociated protein 4 (CTLA-4) та B7 (CD28)), що індукують імунотолерантність [36].

Екзосоми, які утворюються пухлиною, також сприяють диференціації клітин iTreg та MDSC [37]. Супресивна популяція імунних клітин, таких як мієлоїдні клітини Gr1+ CD11b+ на вторинних сайтах тканин і органів, збільшує секрецію регіональних запальних цитокінів S100A8 та calprotectin (S100A9), що сприяє метастатичному засіванню [38, 39]. Показано, що індукція первинною пухлиною експресії S100A8 та S100A9 рекрутує через toll-like receptor 4 (TLR4) мієлоїдні клітини Mac1+ до пре-метастатичних сайтів [13, 40].

Як і в первинних пухлинах, поляризація деяких імунних клітин у пре-метастатичній ніші створює більш сприятливе для росту пухлини середовище. Процес виділення ДНК нейтрофілами спостерігався в сайтах більш ефективної колонізації пухлинних клітин. Екструдована ДНК утворює т. з. нейтрофільні позаклітинні пастки, мережі в процесі, відомому як NETоз [1, 41].

Процес метастазування не є випадковим. Показано, що більшість метастазів утворюється там, де дисеміновані клітини стикаються 3 першим капілярним руслом або лімфатичним вузлом. Досить поширеним місцем метастазів для всіх типів пухлини є кістки. Зараз широким визнанням користується гіпотеза «насіння та грунт». По-перше, пухлинні клітини наділені певними характеристиками, які дозволяють їм пережити кілька етапів метастатичного каскаду. По-друге, вони селективно реагують на сигнали з тканин господаря, так що розподіл метастазів відбувається не випадково, а через комбінацію властивостей клітинного «насіння» та «ррунтом» органу, в якому метастази будуть розвиватися. Нещодавно до гіпотези було додано третій елемент, який є, так би мовити, аналогією клімату [42]. Останній характеризує загальне здоров'я особи та притаманні йому базові генетичні особливості.

Клітинний метаболізм є ключовим для трансформації клітин. Крім того, такі метаболічні функції, як аутофагія та мітофагія, також пов'язані з інвазивною та метастатичною активністю ракових клітин [43]. Очевидно, що необхідна скоординована експресія багатьох генів і існує ієрархія експресії генів, яка відповідає за схильність до утворення метастазів [44]. Припускають, що до складу генів, які надають неопластичним клітинам здатність метастазувати, входять додаткові гени, які визначають, де будуть розвиватися метастази. Виявлені певні регуляторні фактори метастазування.

Відомо також, що деякі тканини є стійкими до пухлинних клітин. Доведено, що каскад wingless and int-1 (Wnt) може взаємодіяти 3 сигналінгом TGF- $\beta$ і контролювати розвиток метастазів у кістках [45]. Нещодавно був ідентифікований компонент 3 системи комплементу, як фактор, що сприяє розвитку лептоменгіальних метастазів [44]. Фактори, що секретуються популяціями myeloid derived suppressor cells (MDSC), можуть впливати на залежний від L-селектину адаптаційний імунітет у лімфатичних вузлах, що, у свою чергу, може вплинути на ефективність метастазування.

Вже згадувалось, що існують такі механізми хомінгу, як хемотаксис та гаптотаксис. Одержані докази, що підтверджують існування хемотаксичних градієнтів. Було встановлено, що пухлинні клітини, які експресують хемокіновий рецептор CXCR4, переважно метастазують у тканини, що експресують ліганд SDF1/CXCL12. Багато механізмів хомінгу, які використовуються лімфоцитами для периферичних лімфатичних вузлів або ділянок запалення, очевидно, є спільними і для пухлинних клітин.

Колонізація вторинних сайтів пухлинними клітинами не завжди супроводжується негайним поділом клітин. Стан спокою часто передує прогресуючому росту. Дисеміновані 
клітини розвиваються як макроскопічні метастази протягом місяців і навіть років після посіву [46]. Вважають, що клітини можуть переходити в стан тимчасового мітотичного арешту або затримуватися протягом тривалого часу у фазах G0-G1 клітинного циклу, можливо, через відсутність достатнього кровопостачання або через імунні механізми (редагування імунітету) [47].

Формування судинної мережі має важливе значення для розповсюдження ракових клітин. Стабільні мікросудини утворюють «сплячу» нішу. Фактори, які підтримують гомеостаз, такі як thrombospondin 1 (TSP-1), що секретується ендотелієм, індукують перехід ракових клітин у стан тривалого спокою. Коли кровоносні судини починають проростати, виробляються нові фактори, які трансформують сплячі ракові клітини в метастатичні пухлини [48], у процесі чого TSP-1 поступається місцем у неоваскулатурі tumour necrosis factor (TNF) та періостину.

Багато прозапальних хемокінів, що утворюються раковими клітинами, підтримують розвиток судин. TNF- $\alpha$ діє опосередковано, індукуючи продукцію та вивільнення VEGF та basic fibroblast growth factor (bFGF) [49]. CXCR4 сприяє міграції ендотеліальних клітин у бік секретованого стромальними клітинами фактора stromal cell-derived factor-1(SDF-1), що є необхідним для розвитку та розгалуження нових судин. Взаємодія SDF-1 - CXCR4 посилює продукцію VEGF ендотеліальними клітинами, a VEGF i bFGF у свою чергу збільшують кількість SDF-1 [49]. VEGFR1+very late antigen-4 (VLA-4)+гематопоетичні попередники мігрують із кісткового мозку до специфічних для пухлини пре-метастатичних ділянок та утворюють клітинні кластери ще до приходу пухлинних клітин. Ці попередники визначають розповсюдження органоспецифічної пухлини через ангіогенез та хемотаксис [13].

Зміни в метаболізмі строми [50] або інші зміни, пов'язані зі старінням [51], можуть бути причиною виходу метастатичних клітин зі спокою. Для покращення результатів терапії метастазів важливе розуміння механізмів, відповідальних за вихід пухлинних клітин зі стану спокою і прехід до активної колонізації вторинних сайтів. Пухлинні клітини, які колонізували вторинний сайт, характеризуються такою ж генетичною нестабільністю, як і клітини первинної пухлини. Відомо, що клітини метастазів можуть повторювати етапи метастазування, описані раніше, і мігрувати на інші сайти [1].

Нервова система також сприяє розвитку метастазів пухлини шляхом модуляції метастатичних каскадів за рахунок вивільнення факторів нервовими закінченнями, таких як нейротропіни, нейромедіатори та нейропептиди. Іннервація пухлини відбувається завдяки здатності ракових клітин залучати нормальні нервові волокна через секрецію сигнальних молекул та нейротропних факторів. Крім того, CSC здатні безпосередньо ініціювати нейрогенез пухлини. Іннервація пухлини впливає на метастазування, оскільки врослі нервові закінчення секретують нейромедіатори, які посилюють метастатичне поширення. Деякі пухлинні клітини експресують рецептори для ряду нейропептидів та нейромедіаторів, таких як норадреналін, епінефрин, дофамін, $\gamma$-аміномасляна кислота (ГАМК), ацетилхолін, субстанція Р та neuropeptide Y (NPY), що стимулюють міграцію ракових клітин [52].

\section{Метастази пухлин щитоподібної залози}

Епітеліально-мезенхімальний перехід. ЕМТ був вперше визначений як процес диференціації на початку ембріогенного морфогенезу. Це скоординований молекулярний і клітинний процес зниження клітинної адгезії, апікально-базолатеральної полярності, епітеліальних маркерів та надбання мобільності, веретено-подібної форми клітин і мезенхімальних маркерів, таких як фібронектин, віментин та N-кадгерин [53, 54]. Процес EMT вказує на потенційний механізм, який посилює відділення ракових клітин від первинних пухлин [53]. У процесі ЕMT беруть участь TGF- $\beta$-, receptor tyrosine kinase $(\mathrm{RTK}) / \mathrm{rat}$ sarcoma viral oncogene homologue (Ras)-, Wnt-, Notch-, Hedgehog- та nuclear factor binding near the $\kappa$ light chain gene in $\mathrm{B}$ cells $(\mathrm{NF}-\kappa \mathrm{B})$ -залежні сигнальні шляхи і автокринні фактори $[54,55]$. TGF- $\beta$, члени родини epidermal growth factor (EGF), HGF i insulin-like growth factor-1 (IGF-1) можуть індукувати EMT автокринним або паракринним чином [55]. 
Крім того, родина мікроРНК-200 відіграє важливу роль в EGF/EGFR-опосередкованій інвазї клітин Щ3 і в ЕMT [56]. Інші мікроРНК - мікроРНК-146b-5p та мікроРНК-222-3р у складі екзосом є потенційними біомаркерами метастазування в лімфатичні вузли при РТС [57]. МікроРНК-483 сприяє, а мікроРНК-873-5р інгібує міграцію клітин та EMT у карциномах Щ3 [58, 59]. Також спостерігалася down-регуляція мікроРНК-7-2-3р та мікроРНК-30c-2-3р в papillary thyroid cancer (PTC) з метастазами в лімфатичні вузли [60].

Е-кадгерин, один із контролерів епітеліального фенотипу, також бере участь в ЕMT у карциномах ЩЗ. Понижуюча регуляція Е-кадгерину була продемонстрована при ЕМТ та утворенні метастазів. Метилювання ДНК промотора гена Е-кадгерину, CDH1, змінюється на різних стадіях метастатичного процесу [61]. Показано, що ЕМТ відіграє важливу роль у міграції ракових клітин ЩЗ. Рівень експресії Е-кадгерину може бути пов'язаний із дедиференціюванням, прогресією і метастазуванням у карциномах ЩЗ. Експресія Е-кадгерину значно нижче в РТС із метастазами в лімфатичних вузлах, ніж за відсутності метастазів. Припускають, що експресія гена і пост-транскрипційний контроль рівня Е-кадгерину можуть бути порушені в пухлинах Щ3 людини. Віментин, мезенхімальний клітинний маркер, часто надекспресований у метастатичних РТС [61].

Збільшення кількості мутацій v-raf murine sarcoma viral oncogene homologue B1 (B-Raf), Ras та промотора telomerase reverse transcriptase (TERT) було виявлено у високодиференційованих карциномах ЩЗ із віддаленими метастазами [62]. Регресійний аналіз підтверджує сильний зв'язок між CXCR4 і B-Raf та ступенем неопластичної інфільтрації. Одержані дані чітко вказують на те, що експресія рецептора хемокіну CXCR4, індукована онкогенною активацією, є основним детермінантом локального розповсюдження пухлинних клітин. Ці спостереження відповідають роботам, які демонструють зв'язок між мутацією B-Raf та інвазивністю пухлини. Експресія CXCR4 та статус мутації B-Raf можуть сприяти більш агресивному фенотипу РТC, зокрема, посилювати поширення пухлини поза Щ3 [63]. Таким чином, тісна перехресна взаємодія між онкоген-активованими сигнальними шляхами i ЕМТ-пов'язаними механізмами сприяють агресивності і метастазам раку ЩЗ.

Агресивність карцином ЩЗ корелює 3 посиленим ангіогенезом, а також експресією рецепторів: VEGF - VEGFR, фактора росту тромбоцитів Platelet-derived growth factors (PDGF) - Platelet-derived growth factors receptor (PDGFR), фактора росту фібробластів (FGF) - FGFR, EGF - EGFR та HGF c-Met (що стимулює або стримує ангіогенез) [64]. VEGF та його основний рецептор VEGFR-2 надекспресуються в DTC і залучені до посилення агресивності та прогресування пухлини. Розробка препаратів, які мають своїми мішенями VEGF є перспективним терапевтичним підходом для лікування раку ЩЗ [65].

Супресори метастазування в пухлинах ЩЗ. Гени-супресори кодують білки, які пригнічують метастазування, не впливаючи на злоякісну трансформацію тканини та ріст первинної пухлини. Було визначено понад тридцять супресорів метастазів [66]. Проте механізми дії для більшості ще не відомі. Зрозуміло, однак, що супресори метастазів знаходяться як у клітинах, так і в позаклітинному середовищі, що їх механізми дії різноманітні, і кожен регулює різні етапи метастатичного каскаду. Деякі з супресорів метастазів сприяють гомотипічній міжклітинній адгезї (Е-кадгерин), що уповільнює початкову міграцію 3 первинної пухлинної маси. Значна кількість супресорів (Nm23, TIMP і Src-suppressed C kinase substrate (SseCKS)) пригнічують мобільність та інвазію і пухлинні клітини залишаються в первинній пухлині. Інші супресори метастазів знижують виживаність клітин під час транзиту від первинної пухлини до вторинних ділянок (каспаза-8, breast carcinoma metastasis suppressor gene 1 (BRMS1) i Kangai 1 (KAI-1)). I, нарешті, підмножина супресорів метастазів гальмує ріст пухлинних клітин після того, як вони вже дисеміновані kisspeptin-1 (KiSS1), mitogen-activated protein kinase kinase (MKK4), mitogen-activated protein kinase (p38MAPK) i MKK7) [67].

Показано, що експресія супресорів метастазування була пригнічена в метастатичних пухлинних клітинах, порівняно з онкогенними, але не метастатичними пухлинними клітинами. Було ідентифіковано понад двадцять 
генів-супресорів [67]. Визначення механізмів утворення метастатичних супресорів може мати потенційне терапевтичне значення.

Також було ідентифіковано цілу низку генів, які кодують фактори, що пригнічують метастази, зокрема Nm23, CAD1, MKK4, KAI-1 (CD82), thioredoxin-interacting protein (TXNIP), calcitonin receptor-stimulating peptide (CRSP3), BRMS1, KiSS-1 та інші. Деякі з цих генів були досліджені в пухлинах Щ3, зокрема Nm23, CAD1, KAI-1, KiSS-1, heptahelical G protein-coupled receptor (GPR54) i regulator of calcineurin (RCAN1-4). Інвазивні та метастатичні пухлини характеризуються пониженою регуляцією $\mathrm{Nm} 23$, CAD1 i KAI-1. KAI-1 є відомим метастатичним геном-супресором, локалізованим у людини на хромосомі 11p11.2, який спочатку був ідентифікований в пухлинах передміхурової залози. Експресія KAI-1 пригнічена в прогресуючій РТC із метастазами в лімфатичні вузли та в їі анапластичній трансформації [61].

Використання моноклональних антитіл для дослідження Nm23-H1 у пацієнтів із фолікулярною карциномою показало вірогідний зворотний зв'язок між метастазуванням і експресією продукту Nm23-H1. Іммунореактивність білка Nm23-H1 була обернено пропорційно пов'язана 3 метастатичним потенціалом пухлин і смертністю пацієнтів із follicular thyroid cancer (FTC). Виявили також, що кількість Nm23-H1 у метастатичній тканині лімфатичних вузлів є нижчою, ніж у первинній пухлині диференційованого раку ЩЗ. Метастін (кісспептин - продукт гена KiSS-1) був описаний в якості інгібітора метастазів у лініях клітин меланоми і карциноми молочної залози. Показано, що GPR54, рецептор кісспептину надекспресується в РТС, але рідко експресується в FTC, оскільки папілярний рак із меншою ймовірністю розвиває віддалені метастази, ніж фолікулярний рак Щ3 [61].

Вплив мікрооточення пухлин ЩЗ. Необхідно відзначити вплив оточення (ніші) пухлини, що визначає іiі утворення i, особливо, розвиток. Під час розвитку пухлини клітини раку постійно контактують із навколишнім мікросередовищем через біохімічні та біофізичні сигнали. Зокрема, мікросередовище пухлини може ініціювати в клітинах карциноми програму морфогенезу - ЕМТ для сприяння місцевій інвазії та метастатичному поширенню [61, 68, 69]. Накопичується все більше даних щодо ролі стромального мікросередовища, яке впливає на розвиток пухлинних клітин, визначає різні стадії прогресування раку, зокрема метастазування пухлинних клітин і регуляцію поведінки трансформованих клітин [61].

Виявлено безліч мікроекологічних факторів, що сприяють ЕМТ, включаючи прозапальні цитокіни (продукти секреції активованих стромальних клітин), стан гіпоксії, компоненти позаклітинного матриксу та механічні властивості строми [68]. Отримані дані свідчать про те, що нормальні клітини організму в межах мікрооточення пухлини також відіграють критичну роль у зміні метастатичної поведінки [70]. Вплив мікросередовища опосередковується, головним чином, через двонаправлені взаємодії між епітеліальними пухлинними клітинами і сусідніми клітинами строми, такими як ендотеліальні та імунні [61]. Взаємодія включає адгезію, протеоліз, міграцію, захист від імунної системи, лімфо-/ангіогенез і хомінг щодо органів-мішеней.

Іноді в РТС спостерігається інфільтрація лімфоцитів, особливо з rearranged during transfection (RET)/РTC перебудовами. Запалення пов'язане 3 розвитком і прогнозом PTC $[71,72]$. Припускають, що конкретні види інфільтрованих лімфоцитів впливають на розмір пухлини і локальне метастазування. Пухлина секретує мікровезикули, що походять із плазматичної мембрани, які несуть матриксні металопротеїнази. Мікровезикули можуть допомогати міграції пухлинних клітин у межах солідної тканини [73].

Екзосоми, що несуть білки, ліпіди і РНК, опосередковують міжклітинну комунікацію різних типів клітин і функціонують у фізіологічному стані і в стані патології [73]. Пухлинні екзосоми можуть брати участь у метастатичному поширенні пухлинних клітин шляхом модифікації клітин-попередників кісткового мозку і сприяння їхній міграції в ділянки майбутніх метастаз, шляхом безпосереднього посіву в лімфатичних вузлах, що дренують пухлину, перед міграцією самих пухлинних клітин або шляхом посилення локальної мобільності пухлинних клітин за допомогою комплексної взаємодії з оточуючими фібробластами $[74,75]$. 
Можлива участь мікрооточення в канцерогенезі Щ3 грунтується на спостереженнях, згідно з якими chronic autoimmune thyroiditis (AIT) може супроводжуватися злоякісною трансформацією тканини Щ3 [72]. Тобто, РТС краще розвивається, у випадку співіснування в залозі клітин з онкогенними мутаціями i AIT. Порушення тканинного гомеостазу через хронічне запалення може створити умови для проліферації клітин, які мають спонтанну $R E T /$ РTC-перебудову [71].

Вже відзначалась роль NF-кB у патогенезi anaplastic thyroid carcinoma (ATC), ефекти якого пов'язані з гальмуванням апоптозу, активацією проліферації клітин, прогресією пухлин, їх інвазивністю, а також стійкістю до опромінення та хіміотерапії. Важливо також зазначити, що опромінення клітин активує сигнальний каскад NF-кB [76]. У карциномах Щ3 спостерігається конститутивна активація NF-кB і значно збільшується кількість мРНК i білка субодиниці фактора - p65, порівняно 3 нормальними клітинами, що підтверджує участь NF-кB в генезі раку Щ3 [77-79].

RET/PTC перебудови, а також B-Raf i Ras мутації ініціюють МАРК-каскад, який, зі свого боку, призводить до активації NF-кB i, опосередкованих онкогенами, прогресії i агресивної поведінки РТС [80]. Показано також, що в клітинах папілярного раку ЩЗ людини, мутація $B$-Raf V600E активує не лише МАРК, але і сигнальний шлях NF-кB, який спричиняє стійкість до апоптозу і посилення інвазивного потенціалу клітин. Нами встановлено зворотний зв'язок між NF-кB i B-Raf - пригнічення активності фактора специфічними інгібіторами призводить до інактивації Raf [81].

Є дані, що RET/PTC3 перебудова може також активувати канонічний шлях NF-кB через стабілізацію NF-кB-індукуючої кінази (NIK) в РTC. Генетичний фон RET/PTC3 пов'язаний із секрецією прозапальних медіаторів (у тому числі granulocyte-macrophage colony-stimulating factor (GM-CSF) i monocyte chemoattractant protein-1 (MCP-1), контрольованих NF-кB) і здатен пригнічувати вроджений імунітет проти раку. Запальний процес хронічно активує NF-кB, що, зі свого боку, стимулює експресію цитокінів, хемокінів, факторів росту і каскадів протеаз, які сприяють ініціації, прогресу пухлин і забезпечують нішу для злоякісної трансформації. Вважається, що касад NF-кB є перспективною терапевтичною мішенню при лікуванні раку Щ3 [69].

Радіотерапія є усталеною терапевтичною модальністю в онкології, яка забезпечує кращу виживаність для кількох різних типів раку i, у першу чергу, карцином ЩЗ. Однак рецидиви раку після променевої терапії часто призводять до більш агресивних станів, які важко лікувати і які мають несприятливий характер. Накопичені дані свідчать, що опромінене пухлинне русло сприяє такій агресивній поведінці, але механізми впливу залишаються ще не до кінця ясними.

Раніше були виявлені нерозпізнані клітинні та молекулярні події, які сприяють росту, інвазії та метастазуванню пухлин, що прогресують в опроміненому мікросередовищі. Клітинні механізми включають пригнічення ангіогенезу, формування стану гіпоксії, активацію та диференціювання стромальних клітин, а також мобілізацію клітин кісткового мозку з васкулогенною та прометастатичною активністю. Ідентифіковані шляхи включають TGF- $\beta$ receptor I kinase (TGF- $\beta /$ ALK5), CXCL12/CXCR4, KIT ligand (KITL)/KIT та cysteine-rich angiogenic inducer 61(CYR61)/ інтегрин $\alpha v \beta 5$, а також Raf-1, MEK, ERK та Elk-1 [82, 83].

\section{Маркери метастазування для карцином щитоподібної залози}

1. Придбання мезенхімальних маркерів, таких як віментин або S100A4 (S100 кальційзв'язуючий білок А4, також відомий як fibroblast-specific protein-1 (FSP1), епітеліальними клітинами карциноми пов'язане 3 підвищеним метастатичним потенціалом, як і ядерна надекспресія $\beta$-катеніну та втрата молекул адгезії, таких як Е-кадгерин, епітеліальними клітинами. Ініціація експресії FSP1 i, можливо, discoidin domain receptor tyrosine kinase 2 (DDR2) пов'язана з порушенням базальної мембрани [54, 84].

2. Підвищена експресія HSP47, колагену I ( $\alpha 1)$, колагену $2(\alpha 2), \mathrm{N}$-кадгерину або віментину, ядерна релокалізація CArG boxbinding factor-A (CBF-A) або $\beta$-катеніну/ lymphoid enhancer factor (LEF), початок експресії факторів транскрипції: Snail, 
Slug або Twist, втрата або часткова втрата маркерів епітелію, таких як цитокератин, E-кадгерин, білка щільних контактів zonula occludens-1 (ZO-1) асоціюється 3 EMT. Для моніторингу прогресу ЕМТ часто використовується заміна (перемикання) E-кадгерину на $\mathrm{N}$-кадгерин, який експресується в мезенхімальних клітинах, фібробластах та клітинах раку. Експресія інтегрину $\alpha 5$ також корелює з метастатичним потенціалом клітин. Іншим маркером ЕMT, який відображає адаптацію до зміненого мікросередовища ЕСМ, асоційованого з ЕМТ, $€$ колаген-специфічна рецепторна тирозинкіназа DDR2, що опосередковує регуляцію MMP1 та мобільність клітин. Uр-регуляція білка ЕСМ ламініну 5 ( $\alpha 3 \beta 3 \gamma 2)$ асоціюється з ЕМТ 3 типу - у злоякісних пухлинах. Ламінін 5, що виявляється в переривчастих структурах ламіну, пов’язаний з інвазивними пухлинами.

3. Експресія FGF19 була локалізована в цитоплазмі злоякісних клітин і спостерігалася у 82 із 100 пацієнтів із раком Щ3. FGF19 асоціюється зі злоякісними пухлинами ЩЗ, що підкреслює його потенціал як молекулярного маркера для ранньої діагностики. FGF19 може функціонувати як ендокринний фактор, який відіграє вирішальну роль у регуляції різних клітинних процесів, таких як метаболізм глюкози, ліпідів та вітаміну D, а також синтез жовчних кислот [85]. Порушення сигнального шляху FGF19/ FGFR4/ $\beta$ Клото ( $\beta \mathrm{KL})$ може відігравати певну роль у розвитку раку ЩЗ. Відомо, що $\beta \mathrm{KL}$ діє як ко-рецептор для FGFR4, який є основним рецептором, що розпізнає FGF19. Порушення регуляції цієї сигнальної осі причетне до патогенезу кількох ракових захворювань [86].

4. АТФ-зв'язуючі касети ABCG2 були високопозитивними на запущених стадіях раку і пов'язані з метастазуванням в лімфатичні вузли.

5. Рухливість і проникнення пухлинних клітин через ендотеліальний шар, базальну мембрану і стимульований ангіогенез навколо пухлин, що розвиваються, здійснюється і регулюються за участю білків клітинної поверхні: ОВ-кадгерину, $\alpha 5 \beta 1$ інтегрину, $\alpha \mathrm{V} \beta 6$ інтегрину, трансмембранного гепарансульфат протеоглікана - синдекана-1.

6. Маркери цитоскелету: FSP1, $\alpha$-smooth muscle actin ( $\alpha$-SMA), які експресуються асоційованими з пухлиною фібробластами, та $\beta$-катенін пов’язані з інвазивністю карциноми.

7. Фактори транскрипції: fibroblast transcription site-1 (FTS-1) є регуляторним елементом і присутній у промоторній області різних генів, пов'язаних з ЕМТ (включаючи ті, що кодують FSP1, Twist, Snail1, high mobility group AT-hook 2 (HMGA2), LEF1, EE26 avian erythroblastosis virus transcription factor-1 (Ets-1), Е-кадгерин, $\beta$-катенін, ZO-1, $\alpha$-SMA та віментин). При розвитку метастатичних ракових клітин до EMT 3 типу Twist може діяти незалежно від Snail1 щодо пригнічення Е-кадгерину i збільшення рівня фібронектину та N-кадгерину. Індуктори EMT TGF- $\beta 1$, Snail, Twist, zinc-finger E-box binding protein 1 (ZEB1), zinc-finger E-box binding protein 2 (ZEB2) або Goosecoid посилюють експреciю forkhead box protein $\mathrm{C} 2$ (FOXC2), який індукує, у свою чергу, ЕМТ [87].

8. У пацієнтів із РТС виявлення ракових стовбурових клітин може бути використане в якості прогностичних маркерів метастазування. Рівні маркерів CD44, CD133 та epithelial cell adhesion molecule (EpCAM) були значно підвищені в тканинах РТС. Виявлена позитивна корреляція між цими маркерами і стадією пухлини, станом лімфатичних вузлів і рівнем метастазування [88].

9. ММP-2 i CD44v6 можуть бути прогностичними маркерами ризику розвитку бічних шийних lymph node metastasis (LNM) у пацієнтів із РТС. До того ж, експресія CD44 сильно корелює з мутацією B-Raf [89]. Присутність ММР-2 у передопераційній сироватці може слугувати біомаркером для діагностики РТС та прогнозним показником для LNM та structurally persistent/recurrent disease (SPRD) у пацієнтів чоловічої статі [90].

10. Асоціація високих рівнів коекспресії VEGF-C, сурвайвіну та активної МMP-9 3 лімфатичними метастазами і локальною інвазивністю РТС говорить про їх потенційну користь як прогностичних біомаркерів 
агресивного РТC [91]. Interleukin-17B (IL-17RB) може посилити інвазію та метастазування пухлинними клітинами Щ3 за допомогою експресії ММР-9, опосередкованої ERK1/2 [92]. Стимуляція TGF- $\beta$ активує pSmad2-залежну експресію S100A4 та MMP-2/9 та посилює міграцію клітин та їх інвазивність [85]. Оцінка рівнів TSP-1 та ITG (integrin) рецепторів може сприяти більш ранньому виявленню метастатичного потенціалу B-RafV600Е-позитивного агресивного раку Щ3 - АТС [93].

11. Up-регуляція MUC15 (MUCIN15) сильно корелює з прогресуванням раку Щ3. MUC15 відіграє важливу роль у формуванні сфер (ключова характеристика стовбурових клітин i CSC), як це видноз експресії маркерів стовбурових клітин, таких як sex determining region Y (SRY)-box 2 (SOX2), Krüppel-like factor 4 (KLF4), aldehyde dehydrogenase1(ALDH1) A3 і інтерлейкін 6 (IL6). Крім того, MUC15 активує ектопічну експресію ERK через G-protein-coupled receptor (GPCR/cAMP) та шлях інтегрин/кіназа фокальної адгезії. MUC15 відіграє найважливішу роль у опосередковуванні стовбурових властивостей клітин пухлин ЩЗ. Високі показники експресії MUC15 у пухлинах корелюють із віком, віддаленими метастазами та наявністю мультифокальності. Ектопічна експресія MUC1 підвищує рівень CSC-маркерів, таких як OCT4, SOX2, ALDH1A1, IL6 та CXCR4. Вважається, що ир-регуляція MUC1 суттєво сприяє агресивності РТС. Так само, up-регуляція MUC4 спостерігається у 20\% клітин РТС порівняно з нормальними клітинами [94].

12. Одними 3 найважливіших маркерів метастазування для папілярної карциноми Щ3, особливо щодо утворення йодрезистентних метастазів, є рівні експресії тироглобуліну, тиреоїдної пероксидази та, меншою мірою, цитокератину-17 [95, 96].

\section{Висновки}

1. Давно визнано, що метастазування є надзвичайно складним процесом. Успіхи в розумінні цього процесу були обмежені саме через його складність. По мірі того, як стають відомими нові факти щодо генетичних змін в клітинах, стає все більш очевидним, що взаємодія між генами, пов'язаними 3 канцерогенезом і мікросередовищем пухлини відіграє все більшу роль у моделюванні та концептуалізації механізмів метастазування.

2. Хоча у випадку папілярної карциноми щитоподібної залози метастази утворюються не так часто, як при інших типах раку, все ж спостерігається значний відсоток рецидивів хвороби з формуванням метастазів у лімфатичні вузли, легені та кістки. Особливу небезпеку становлять радіойод-резистентні метастази, які є основною причиною летальних випадків. Тому дослідження маркерів метастазування є важливим на перед- і післяопераційному етапах лікування хворих із метою оцінки ймовірності виникнення метастазів у найближчій та віддаленій перспективах.

\section{Список використаної літератури}

1. Welch DR, Hurst DR. Defining the hallmarks of metastasis. Cancer Res. 2019;79(12):3011-27.

2. McGranahan N, Swanton C. Cancer evolution constrained by the immune microenvironment. Cell. 2017;170(5):825-7.

3. McGranahan N, Swanton C. Clonal heterogeneity and tumor evolution: Past, present, and the future. Cell. 2017;168(4):613-28.

4. Bentolila LA, Prakash R, Mihic-Probst D, Wadehra M, Kleinman HK, Carmichael TS, et al. Imaging of angiotropism/vascular cooption in a murine model of brain melanoma: implications for melanoma progression along extravascular pathways. Sci Rep. 2016;6:23834

5. Welch DR. Tumor heterogeneity - a 'contemporary concept' founded on historical insights and predictions. Cancer Res. 2016;76(1):4-6.

6. Hunter KW, Amin R, Deasy S, Ha NH, Wakefield L. Genetic insights into the morass of metastatic heterogeneity. Nat Rev Cancer. 2018;18(4):211-23.

7. Liu R, Wang X, Chen GY, Dalerba P, Gurney A, Hoey T, et al. The prognostic role of a gene signature from tumorigenic breast-cancer cells. N Engl J Med. 2007;356(3):217-26.

8. Bohl CR, Harihar S, Denning WL, Sharma R, Welch DR Metastasis suppressors in breast cancers: mechanistic insights and clinical potential. J Mol Med. 2014;92(1):13-30.

9. van der Horst G, Bos L, van der Pluijm G. Epithelial plasticity, cancer stem cells, and the tumor-supportive stroma in bladder carcinoma. Mol Cancer Res. 2012;10(8):995-1009.

10. Romano S, Tufano M, D'Arrigo P, Vigorito V, Russo S, Romano MF Cell stemness, epithelial-to-mesenchymal transition, and immunoevasion: Intertwined aspects in cancer metastasis. Semin Cancer Biol. 2020;60:181-90.

11. Steinbichler TB, Savic D, Dudás J, Kvitsaridze I, Skvortsov S, Riechelmann H, Skvortsova II. Cancer stem cells and their unique role in metastatic spread. Semin Cancer Biol. 2020;60:148-56.

12. Liu, Y, Cao, X. Characteristics and significance of the premetastatic niche. Cancer Cell. 2016;30(5):668-81.

13. Zhang $X$, Xiang J. Remodeling the microenvironment before occurrence and metastasis of cancer. Int J Biol Sci. 2019;15(1):105-13

14. Peinado H, Zhang H, Matei IR, Costa-Silva B, Hoshino A, Rodrigues G, et al. Pre-metastatic niches: organ-specific homes for metastases. Nat Rev Cancer. 2017;17(5):302-17.

15. Zhang H, Freitas D, Kim HS, Fabijanic K, Li Z, Chen H, et al. Identification of distinct nanoparticles and subsets of extracellular 
Огляди

vesicles by asymmetric flow field- flow fractionation. Nat Cell Biol. 2018;20(3): 332-43.

16. Sansone P, Savini C, Kurelac I, Chang Q, Amato LB, Strillacci A, et al. Packaging and transfer of mitochondrial DNA via exosomes regulate escape from dormancy in hormonal therapy-resistant breast cancer. Proc Natl Acad Sci U S A. 2017;114(43): E9066-75.

17. Matei I, Kim HS, Lyden D. Unshielding exosomal RNA unleashes tumor growth and metastasis. Cell. 2017;170(2):223-5.

18. Cox TR, Rumney RMH, Schoof EM, Perryman L, Hoye AM, Agrawal A, et al. The hypoxic cancer secretome induces pre-metastatic bone lesions through lysyl oxidase. Nature. 2015;522(7554):106-10.

19. Li L, Li C, Wang S, Wang Z, Jiang J, Wang W, et al. Exosomes derived from hypoxic oral squamous cell carcinoma cells deliver miR-21 to normoxic cells to elicit a prometastatic phenotype. Cancer Res. 2016;76(7):1770-80.

20. Wang X, Luo G, Zhang K, Cao J, Huang C, Jiang T, et al. Hypoxic tumor-derived exosomal miR-301a mediates M2 macrophage polarization via PTEN/PI3Kgamma to promote pancreatic cancer metastasis. Cancer Res. 201878(16):4586-98.

21. Yang $\mathrm{H}, \mathrm{Fu} \mathrm{H}, \mathrm{Xu} \mathrm{W}$, Zhang $\mathrm{X}$. Exosomal non-coding RNAs: a promising cancer biomarker. Clin Chem Lab Med. 2016;54(12):1871-9.

22. Stuelten CH, Parent CA, Montell DJ. Cell motility in cancer invasion and metastasis: insights from simple model organisms. Nat Rev Cancer. 2018;18(5):296-312.

23. Neophytou C, Boutsikos P, Papageorgis P. Molecular mechanisms and emerging therapeutic targets of triple-negative breast cancer metastasis. Front Oncol. 2018:8:31.

24. Gkretsi V, Stylianopoulos T. Editorial: Metastasis: From Cell Adhesion and Beyond. Front Oncol. 2019;9:214.

25. Naba A, Clauser KR, Lamar JM, Carr SA, Hynes RO. Extracellular matrix signatures of human mammary carcinoma identify novel metastasis promoters. Elife. 2014;3: e01308.

26. Moon HJ, Finney J, Xu L, Moore D, Welch DR, Mure M. MCF-7 cells expressing nuclear associated lysyl oxidase-like 2 (LOXL2) exhibit an epithelial-to-mesenchymal transition (EMT) phenotype and are highly invasive in vitro. J Biol Chem. 2013;288(42):30000-8.

27. Hamidi H, Ivaska J. Every step of the way: integrins in cancer progression and metastasis. Nat Rev Cancer. 2018;18(9):533-48.

28. Mason SD, Joyce JA. Proteolytic networks in cancer. Trends Cell Biol. 2011; 21(4):228-37.

29. Revach OY, Geiger B. The interplay between the proteolytic, invasive, and adhesive domains of invadopodia and their roles in cancer invasion. Cell Adh Migr. 201;8(3):215-25.

30. Carron EC, Homra S, Rosenberg J, Coffelt SB, Kittrell F, Zhang Y, et al. Macrophages promote the progression of premalignant mammary lesions to invasive cancer. Oncotarget. 2017;8(31):50731-46.

31. Ao Z, Shah SH, Machlin LM, Parajuli R, Miller PC, Rawal S, et al. Identification of cancer-associated fibroblasts in circulating blood from patients with metastatic breast cancer. Cancer Res. 2015;75(22):4681-7.

32. Gkountela S, Castro-Giner F, Szczerba BM, Vetter M, Landin J, Scherrer R, et al. Circulating tumor cell clustering shapes DNA methylation to enable metastasis seeding. Cell. 2019; 176(1-2):98-112.

33. Cho EJ, Kim MH, Cha SH, Hyun S, Jeong S, Lee JD. Breast cancer cutaneous metastasis at core needle biopsy site. Ann Dermatol. 2010;22(2):238-40

34. Folkman J. Angiogenesis. Annu Rev Med. 2006;57:1-18.

35. Albrengues J, Shields MA, Ng D, Park CG, Ambrico A, Poindexter ME, et al. Neutrophil extracellular traps produced during inflammation awaken dormant cancer cells in mice. Science 2018;361(6409): eaao4227.

36. Lu Z, Hunter T. Metabolic kinases moonlighting as protein kinases. Trends Biochem Sci. 2018;43(4):301-10.

37. Wang W, Wang L, Ruan L, Oh J, Dong X, Zhuge Q, et al. Extracellular vesicles extracted from young donor serum attenuate inflammaging via partially rejuvenating aged T-cell immunotolerance. FASEB J. 2018;32(11): fj201800059R.

38. Klassen LMB, Chequin A, Manica GCM, Biembengut IV, Toledo MB, Baura VA, et al. MMP9 gene expression regulation by intragenic epigenetic modifications in breast cancer. Gene. 2018;642:461-6.
39. Fei F, Liu K, Li C, Du J, Wei Z, Li B, et al. Molecular mechanisms by which S100A4 regulates the migration and invasion of PGCCs with their daughter cells in human colorectal cancer. Front Oncol. 2020;10:182.

40. Ma L, Sun P, Zhang JC, Zhang Q, Yao SL. Proinflammatory effects of S100A8/A9 via TLR4 and RAGE signaling pathways in BV-2 microglial cells. Int J Mol Med. 2017;40(1):31-8.

41. Cedervall J, Zhang YY, Olsson AK. Tumor-induced NETosis as a risk factor for metastasis and organ failure. Cancer Res. 2016;76(15):4311-5.

42. Beadnell TC, Scheid AD, Vivian CJ, Welch DR. Roles of the mitochondrial genetics in cancer metastasis: not to be ignored any longer. Cancer Metastasis Rev. 2018;37(4):615-32.

43. Mowers EE, Sharifi MN, Macleod KF. Functions of autophagy in the tumor microenvironment and cancer metastasis. FEBS J. 2018;285(10):1751-66.

44. Boire A, Zou Y, Shieh J, Macalinao DG, Pentsova E, Massague J. Compement component 3 adapts the cerebrospinal fluid for leptomeningeal metastasis. Cell. 2017;168(6):1101-13.

45. Zhuang X, Zhang H, Li X, Li X, Cong M, Peng F, et al. Differential effects on lung and bone metastasis of breast cancer by Wnt signalling inhibitor DKK1. Nat Cell Biol. 2017;19(10):1274-85.

46. Aguirre-Ghiso JA, Sosa MS. Emerging topics on disseminated cancer cell dormancy and the paradigm of metastasis. Annu Rev Cancer Biol. 2018;2:377-93.

47. Manjili MH. A theoretical basis for the efficacy of cancer immunotherapy and immunogenic tumor dormancy: the adaptation model of immunity. Adv Cancer Res. 2018;137:17-36.

48. Ghajar CM, Peinado H, Mori H, Matei IR, Evason KJ, Brazier H, et al. The perivascular niche regulates breast tumour dormancy. Nat Cell Biol. 2013;15(7):807-17.

49. Patel LR, Camacho DF, Shiozawa Y, Pienta KJ, Taichman RS Mechanisms of cancer cell metastasis to the bone: a multistep process. Future Oncol. 2011;7(11):1285-97.

50. Yumoto K, Eber MR, Berry JE, Taichman RS, Shiozawa Y Molecular pathways: niches in metastatic dormancy. Clin Cancer Res. 2014;20(13):3384-9.

51. Kaur A, Ecker BL, Douglass SM, Kugel CH III, Webster MR, Almeida FV, et al. Remodeling of the collagen matrix in aging skin promotes melanoma metastasis and affects immune cell motility. Cancer Discov. 2019;9(1):64-81.

52. Kuol N, Stojanovska L, Apostolopoulos V, Nurgali K. Role of the nervous system in cancer metastasis. J Exp Clin Cancer Res. 2018;37(1):5

53. Tsuji T, Ibaragi S, Hu GF: Epithelial-mesenchymal transition and cell cooperativity in metastasis. Cancer Res. 2009;69(18):7135-9.

54. Baquero P, Sánchez-Hernández I, Jiménez-Mora E, Orgaz JL, Jiménez B, Chiloeches A. (V600E)BRAF promotes invasiveness of thyroid cancer cells by decreasing E-cadherin expression through a Snail-dependent mechanism. Cancer Lett. 2013;335(1):232-41.

55. Huber MA, Kraut N, Beug $\mathrm{H}$. Molecular requirements for epithelial-mesenchymal transition during tumor progression. Curr Opin Cell Biol. 2005;17(5):548-58

56. Zhang Z, Liu ZB, Ren WM, Ye XG, Zhang YY. The miR-200 family regulates the epithelial-mesenchymal transition induced by EGF/EGFR in anaplastic thyroid cancer cells. Int J Mol Med. 2012;30(4):856-62

57. Jiang K, Li G, Chen W, Song L, Wei T, Li Z, et al. Plasma exosomal miR-146b-5p and miR-222-3p are potential biomarkers for lymph node metastasis in papillary thyroid carcinomas. Onco Targets Ther. 2020;13:1311-9.

58. Zhang X, Liu L, Deng X, Li D, Cai H, Ma Y, et al. MicroRNA 483$3 p$ targets Pard3 to potentiate TGF- $\beta 1$-induced cell migration, invasion, and epithelial-mesenchymal transition in anaplastic thyroid cancer cells. Oncogene. 2019;38(5):699-715.

59. Wang Z, Liu W, Wang C, Ai Z. miR-873-5p inhibits cell migration and invasion of papillary thyroid cancer via regulation of CXCL16. Onco Targets Ther. 2020;13:1037-46.

60. Saiselet M, Gacquer D, Spinette A, Craciun L, DecaussinPetrucci M, Andry G, et al. New global analysis of the microRNA transcriptome of primary tumors and lymph node metastases of papillary thyroid cancer. BMC Genomics. 2015;16:828.

61. Xie J, Fan, Y, Zhang X. Molecular mechanisms in differentiated thyroid cancer. Front Biosci (Landmark ed.). 2016;21:119-29. 
62. Song E, Song DE, Ahn J, Kim TY, Kim WB, Shong YK, et al. Genetic profile of advanced thyroid cancers in relation to distant metastasis. Endocr Relat Cancer. 2020; ERC-19-0452.R1.

63. Torregrossa L, Giannini R, Borrelli N, Sensi E, Melillo RM, Leocata P, et al. CXCR4 expression correlates with the degree of tumor infiltration and BRAF status in papillary thyroid carcinomas. Modern Pathology. 2012;25(1):46-55.

64. Tan A, Xia N, Gao F, Mo Z, Cao Y. Angiogenesis-inhibitors for metastatic thyroid cancer. Cochrane Database Syst Rev. 2010;2010(3): CD007958.

65. Ferrari SM, Fallahi P, Ruffilli I, Elia G, Ragusa F, Paparo SR, et al. Molecular testing in the diagnosis of differentiated thyroid carcinomas. Gland Surg. 2018;7(Suppl 1): S19-29.

66. Hurst DR, Welch DR. Metastasis suppressor genes at the interface between the environment and tumor cell growth. Int Rev Cell Mol Biol. 2011;286:107-80.

67. Cook LM, Hurst DR, Welch DR. Metastasis suppressors and the tumor microenvironment. Semin Cancer Biol. 2011;21(2):113-22.

68. Олейник ЕК, Шибаев МИ, Игнатьев КС, Олейник ВМ, Жулай ГА. Микроокружение опухоли: формирование иммунного профиля. Медицинская Иммунология. 2020;22(2):20720. (Oleinik EK, Shibaev MI, Ignatiev KS, Oleinik VM, Zhulai GA. Tumor microenvironment: the formation of the immune profile. Med Immunol (Russia). 2020;22(2):207-220. (In Russ.))

69. Li X, Abdel-Mageed AB, Mondal D, Kandil E. The nuclear factor kappa-B signalling pathway as a therapeutic target against thyroid cancers. Thyroid. 2013;23(2):209-18.

70. Peinado H, Lavotshkin S, Lyden D. The secreted factors responsible for pre-metastatic niche formation: old sayings and new thoughts. Semin Cancer Biol. 2011;21(2):139-46.

71. Guarino V, Castellone MD, Avilla E, Melillo RM. Thyroid cancer and inflammation. Mol Cell Endocrinol. 2010;321(1):94-102.

72. Muzza M, Degl'Innocenti D, Colombo C, Perrino M, Ravasi E, Rossi S, et al. The tight relationship between papillary thyroid cancer, autoimmunity and inflammation: clinical and molecular studies. Clin Endocrinol. 2010;72(5):702-8.

73. Colombo M, Raposo G, Thery C. Biogenesis, secretion, and intercellular interactions of exosomes and other extracellular vesicles. Annu Rev Cell Dev Biol. 2014;30:255-89.

74. Peinado JM, Leao C. Nicolau van Uden, a life with yeasts (19211991). IUBMB Life. 2012;64(6):556-60.

75. Luga V, Zhang L, Viloria-Petit AM, Ogunjimi AA, Inanlou MR. Exosomes mediate stromal mobilization of autocrine Wnt-PCP signaling in breast cancer cell migration. Cell. 2012;151(7):1542-56.

76. Pushkarev VM, Kovzun OI, Pushkarev VV, Guda BB, Tronko MD Biochemical aspects of the combined use of taxanes, irradiation and other antineoplastic agents for the treatment of anaplastic thyroid carcinoma. Ukr Biochem J. 2018;90(5):5-19.

77. Pacifico F, Leonardi A. Role of NF-kappaB in thyroid cancer. Mol Cell Endocrinol. 2010;321(1):29-35.

78. Giuliani C, Bucci I, Napolitano G. The role of the transcription factor Nuclear Factor-kappa B in thyroid autoimmunity and cancer. Front Endocrinol.2018;9:471.

79. Pires BRB, Silva RCMC, Ferreira GM, Abdelhay E. NF-kB: two sides of the same coin. Genes. 2018;9(1):24.

80. Spitschak A, Meier C, Kowtharapu B, Engelmann D, Pützer BM. MiR-182 promotes cancer invasion by linking RET oncogene activated NF- $\kappa \mathrm{B}$ to loss of the HES1/Notch1 regulatory circuit. Mol Cancer. 2017;16(1):24.

81. Pushkarev VV, Starenki DV, Pushkarev VM, Kovzun OI, Tronko $\mathrm{MD}$. Inhibitor of the transcription factor $\mathrm{NF}-\kappa \mathrm{B}$, DHMEQ, enhances the effect of paclitaxel on cells of anaplastic thyroid carcinoma in vitro and in vivo. Ukr Biochem J. 2015;87(3):33-44.

82. Kuonen F, Secondini C, Rüegg C. Molecular pathways: emerging pathways mediating growth, invasion, and metastasis of tumors progressing in an irradiated microenvironment. Clin Cancer Res. 2012;18(19):5196-202.

83. Hou CH, Lin FL, Hou SM, Liu JF. Cyr61 promotes epithelialmesenchymal transition and tumor metastasis of osteosarcoma by Raf-1/MEK/ERK/Elk-1/TWIST-1 signaling pathway. Mol Cancer. 2014;13:236.

84. Liang H, Zhong Y, Luo Z, Huang Y, Lin H, Zhan S, et al. Diagnostic value of 16 cellular tumor markers for metastatic thyroid cancer: an immunohistochemical study. Anticancer Res. 2011;31(10):3433-40.
85. Zhang X, Wang Z, Tian L, Xie J, Zou G, Jiang F. Increased expression of FGF19 contributes to tumor progression and cell motility of human thyroid cancer. Otolaryngol Head Neck Surg. 2016;154(1):52-8.

86. Motylewska E, Stępień T, Borkowska M, Kuzdak K, Siejka A Komorowski J, et al. Alteration in the serum concentrations of FGF19, FGFR4 and $\beta$ Klotho in patients with thyroid cancer. Cytokine. 2018;105:32-6.

87. Da C, Wu K, Yue C, Bai P, Wang R, Wang G, et al. N-cadherin promotes thyroid tumorigenesis through modulating major signaling pathways. Oncotarget. 2017;8(5):8131-42.

88. Lin Z, Lu X, Li W, Sun M, Peng M, Yang H, et al. Association of cancer stem cell markers with aggressive tumor features in papillary thyroid carcinoma. Cancer Control. 2015;22(4):508-14.

89. Han SA, Jang JH, Won KY, Lim SJ, Song JY. Prognostic value of putative cancer stem cell markers (CD24, CD44, CD133, and ALDH1) in human papillary thyroid carcinoma. Pathol Res Pract. 2017;213(8):956-63.

90. Shi Y, Su C, Hu H, Yan H, Li W, Chen G, et al. Serum MMP-2 as a potential predictive marker for papillary thyroid carcinoma. PLoS One. 2018;13(6): e0198896.

91. Selemetjev S, Savin S, Paunovic I, Tatic S, Cvejic D. Concomitant high expression of survivin and vascular endothelial growth factor- $\mathrm{C}$ is strongly associated with metastatic status of lymph nodes in papillary thyroid carcinoma. J Can Res Ther. 2018;14(Suppl): S114-9.

92. Ren L, Xu Y, Liu C, Wang S, Qin G. IL-17RB enhances thyroid cancer cell invasion and metastasis via ERK1/2 pathway-mediated MMP-9 expression. Mol Immunol. 2017;90:126-35.

93. Duquette M, Sadow PM, Lawler J, Nucera C. Thrombospondin-1 silencing down-regulates integrin expression levels in human anaplastic thyroid cancer cells with BRAF(V600E): new insights in the host tissue adaptation and homeostasis of tumor microenvironment. Front Endocrinol (Lausanne). 2013;4:189.

94. Choi C, Thi Thao Tran N, Van Ngu T, Woong Park S, Suk Song M, Hyun Kim S, et al. Promotion of tumor progression and cancer stemness by MUC15 in thyroid cancer via the GPCR/ERK and integrin-FAK signaling pathways. Oncogenesis. 2018;7(11):85

95. Тронько МД, Гулеватий СВ, Совенко ТК, Матящук СІ, Марков ВВ, Божок ЮМ, Зелінська ГВ. Діагностика та радіонуклідне лікування тиреоїдного раку у хворих молодого віку. Ендокринологія. 2013;1=8(2):5-10 (Tronko MD, Gulevaty SV, Sovenko TK, Matyashchuk SI, Markov VV, Bozhok YuM, Zelinska GV. Diagnostics and radionuclide therapy of thyroid cancer in young patients. Endokrynologia. 2013;8(2):5-10)

96. Zelinskaya A. Immunocytochemical characteristics of thyrocytes in radioiodine refractory metastases of papillary thyroid cancer. Exp Oncol. 2019;41(4):342-345.

(Надійшла до редакції 14.07.2020р.)

\section{Молекүлярные механизмы образования метастазов. Маркеры метастазирования при карциноме щитовидной железы (обзор литературы)}

\section{П.П. Зиныч, В.М. Пушкарев, М.Ю. Болгов, Б.Б. Гуда, В.В. Пушкарев}

ГУ «Институт эндокринологии и обмена веществ им. В.П. Комиссаренко НАМН Украины»

Резюме. Метастазы являются причиной 90\% смертей от солидных опухолей. Процесс метастазирования предусматривает выход раковых клеток из первичной опухоли, их переход в кровеносную или другую транспортную систему и, наконец, колонизация и пролиферация в отдаленном органе.

В обзоре описан процесс развития метастатической клетки, обусловленный генетическими, эпигенетическими, позиционными 
Огляди

изменениями, сигналами окружающих клеток. Во время эпителиально-мезенхимального перехода опухолевые клетки частично и временно дедифференцируются, меняют свою форму в сторону неполяризованной, подвижной, веретенообразной клетки. Этот переход дает возможность наладить экспрессию генов и приобрести фенотип стволовых клеток. Рассматриваются также механизмы мобильности и инвазивности опухолевых клеток, процессы интравазации, транспортировки, хоминга.

Значительное внимание уделено образованию пре-метастатической ниши, которая характеризуется иммуносупрессией, воспалительными процессами, интенсивным ангиогенезом, пермеабилизацией сосудов, активным лимфангиогенезом специфическим органотропизмом и высокой эффективностью перепрограммирования. Подробно проанализирован процесс колонизации метастатической ниши опухолевыми клетками, участие в нем клеток иммунной системы, других клеток крови, прогениторов костного мозга, экзосом, которые образуются в окружении первичной опухоли, метаболических ферментов и провоспалительных цитокинов.

Акцент сделан на процессе метастазирования опухолей щитовидной железы (ЩЖ). Приведены и проанализированы основные маркеры метастазирования для карцином ЩЖ для всех этапов метастатического каскада. Описаны супрессоры метастазирования, оценено влияние микроокружения опухоли, значение воспали тельных процессов и других патологий в возникновении и прогрессии карцином щитовидной железы.

Ключевые слова: метастазы, щитовидная железа, метастатическая ниша, эпителиально-мезенхимальный переход, миграция и интравазация опухолевых клеток.

\section{Molecular mechanisms of the formation of metastases. Markers of metastasis in thyroid carcinoma (review literary)}

\section{P.P. Zinich, V.M. Pushkarev, M. Yu. Bolgov, B.B. Guda, V.V. Pushkarev}

SI «V.P. Komisarenko Institute of Endocrinology and Metabolism, Natl. Acad. Med. Sci. of Ukraine»

\begin{abstract}
Metastases account for $90 \%$ of deaths from solid tumors. The metastasis process involves the exit of cancer cells from the primary tumor, their transition into the circulatory or other transport system, and finally, colonization and proliferation in a distant organ The review describes the process of metastatic cell development due to genetic, epigenetic, positional changes, and signals from surrounding cells. During the epithelial-mesenchymal transition, the tumor cells partially and temporarily dedifferentiate, change
\end{abstract}

their shape towards an unpolarized, mobile, spindle-shaped cell. This transition makes it possible to establish gene expression and acquire the stem cell phenotype. The mechanisms of mobility and invasiveness of tumor cells, the processes of intravasation, transportation, and homing are also considered.

Considerable attention is paid to the formation of a pre-metastatic niche, which is characterized by immunosuppression, inflammatory processes, intense angiogenesis, vascular permeabilization, active lymphangiogenesis, specific organotropism and high reprogramming efficiency. The process of colonization of a metastatic niche by tumor cells, the participation of cells of the immune system, other blood cells, bone marrow progenitors, exosomes, which are formed in the environment of a primary tumor, metabolic enzymes and pro-inflammatory cytokines, are analyzed in detail.

The emphasis is made on the metastatic processes in the thyroid tumors. The main markers of metastasis for thyroid carcinomas for all stages of the metastatic cascade are presented and analyzed. Suppressors of metastasis have been described, the effect of the tumor microenvironment, the importance of inflammatory processes and other pathologies in the occurrence and progression of thyroid carcinomas have been assessed.

Keywords: metastases, thyroid, metastatic niche, epithelial-mesenchymal transition, migration and intravization of tumor cells.

Для цитування: Зінич ПП, Пушкарьов ВМ, Болгов МЮ, Гуда ББ, Пушкарьов ВВ. Молекулярні механізми утворення метастазів. Маркери метастазування при карциномах щитоподібної залози (Огляд літератури). Ендокринологія. 2020;25(3):227-242. DOI: 10.31793/1680-1466.2020.25-3.227

Відомості про авторів: Петро Петрович Зінич, канд. мед. наук, старш. наук. співр., ORCID: 0000-0001-8890-4343; Володимир Михайлович Пушкарьов, д-р біол. наук, старш. наук. співр., ORCID: 0000-0003-0347-7771; Михайло Юрійович Болгов, д-р мед. наук, старш. наук. співр., ORCID: 0000-0002-9011-9982; Богдан Богданович Гуда, д-р мед. наук, ORCID: 0000-0002-9181-0679; Віктор Володимирович Пушкарьов, канд. біол. наук, ORCID: 0000-0001-59405510.

Особистий внесок: П.П. Зінич, В.М. Пушкарьов, М.Ю. Болгов написання статті. Б.Б. Гуда, В.В. Пушкарьов - оформлення статті, підготовка до друку, переклад резюме.

Фінансування: Стаття підготована в рамках бюджетного фінансування НАМН України.

Декларація з етики: Автори задекларували відсутність конфлікту інтересів і фінансових зобов'язань. 